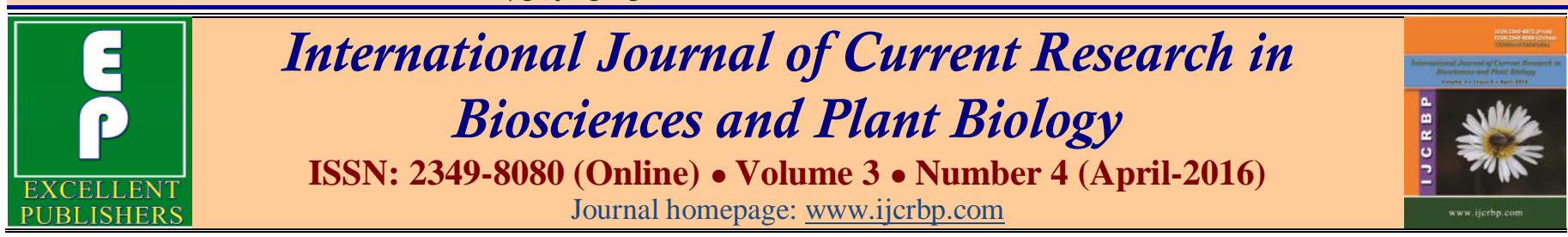

\title{
Role of Egg, Garlic and Fenugreek during Pregnancy and Lactation in Swiss Albino Mice
}

\author{
Ragini Sharma, Amrita Jaitawat*, Neelam Jain, Deepika Rani and Mahima Suthar \\ Department of Zoology, University College of Science, Mohanlal Sukhadia University, Udaipur-313 oo1, Rajasthan, India \\ *Corresponding author.
}

\begin{abstract}
A bstract
Pregnancy is a stage when nutritional requirement is higher, so proper nutrition during pregnancy is very important aspect for the development of fetus. The present study was accomplished to evaluate the role of high protein rich egg and antioxidant containing garlic and fenugreek during pregnancy and lactation in Swiss albino mice. To evaluate the role of egg, garlic and fenugreek selected pregnant females were divided into six groups with 6 animals in each group. These groups were Control Diet group-1 [ $(3.85 \mathrm{~g}$ Wheat $+3.85 \mathrm{~g}$ Maize $+1.55 \mathrm{~g}$ Gram $+0.75 \mathrm{~g}$ Groundnut $=10 \mathrm{~g}$ ) for 1 mice], Control Diet + High Protein (eggs) group-2 [6 g $+4 \mathrm{ml}]$, Control Diet +Garlic (Bulb) group- 3 $[9.5 \mathrm{~g}+0.5 \mathrm{~g}]$, Control Diet + Fenugreek (Seeds) group- $4[9.5 \mathrm{~g}+0.5 \mathrm{~g}]$, Control Diet + Egg + Garlic group- 5[5.5 g $+4 \mathrm{ml}+0.5 \mathrm{~g}]$, Control Diet + Egg + Fenugreek group- 6 $[5.5 \mathrm{~g}+4 \mathrm{ml}+0.5 \mathrm{~g}]$. After parturition the body weight (BW), crown to rump length (CRL) and body mass index (BMI) of pups were recorded on PND (Post Natal Day) 1, PND 7, PND 14, PND 21, PND 35 and PND 49. In all studied groups there were no significant changes observed in BW of pups when mothers fed during pregnancy and lactation at PND 7 while at PND 21 significant changes were observed and highly significant changes occurred at all other days in all groups. There were no significant changes in CRL of pups when mothers fed during pregnancy and lactation at PND 35, 49 in all groups, while highly significant changes were observed at all other post-natal days in all groups and along with it highly significant changes occurred in BMI in all the groups' at all postnatal days.
\end{abstract}

\section{Introduction}

Pregnancy is a period of increased metabolic demands with changes in a women's physiology because of the requirements of a growing fetus (Pipkin, 2007). During pregnancy energy requirement increases in the first trimester up to $375 \mathrm{~kJ} / \mathrm{day}$, in the second trimester up to $1200 \mathrm{~kJ} /$ day and in the third trimester up to $1950 \mathrm{~kJ} /$ day (Prentice and Goldberg, 2000; Butte and King, 2005). A balanced, nutritious diet is therefore an important aspect of a healthy pregnancy. Among macronutrient protein egg is a good source of several important nutrients

\section{Article Info}

Accepted: 12 March 2016

Available Online: 06 April 2016

Keywords

Diet

Fenugreek

Fetus

Garlic

Post-natal

Protein 
causes oxidative damage to nucleic acids, lipids, proteins (Agarwal and Sohal, 1994; Beckman and Ames, 1998; Halliwell and Gutteridge, 1999; Young and Woodside 2001; Levine, 2002). Antioxidant neutralizes freeradicals by donating an electron to free- radicals (Halliwell et al., 1995).

Plant based diet with high intake of fruits; vegetables and other nutrients rich plant food are good source of antioxidants. Therefore plant based diet reduces the risk of oxidative stress related diseases like prevention of cancers of alimentary canal (Johnson, 2004; Riboli and Norat, 2003; World Cancer Research Fund, 2007), ischemic stroke (Joshipura et al., 1999), coronary heart disease (Joshipura et al., 2001). They also help in cell maintenance and DNA repair (Astley et al., 2004).

Garlic (Allium sativum) is a rich source of nutrients and also a very good source of energy. Researchers have worked on transfer of amino acid and fats especially omega-3- fatty acid across the placenta (Schneider et al., 1979; Jones et al., 2014). Allium has been reported to be effective in reducing body weight. Fenugreek (Trigonella foenum-graecum) is a natural means to increase milk supply in women. Researchers indicated that fenugreek seed extract supplementation help in reducing the body and adipose tissue weight (Handa et al., 2005; Geetha et al., 2011). Body mass index or quetelet index is an estimate of body composition that correlates individual weight and height to lean body mass. BMI plays important role in pregnancy, a mother who is underweight prior to becoming pregnant put her baby at risk of complications because of association between underweight status and malnutrition (Chu et al., 2007).

Previously many studies have been done on the egg, garlic and fenugreek in adults but information on developmental stages is very scanty. So to fulfill this lacuna the present study is focused on the effects of these antioxidants on morphology of Swiss albino mice when given alone and in combination especially during pregnancy and lactation.

\section{Materials and methods}

The experiments were conducted in the Environmental and Developmental Toxicology Research Laboratory, Department of Zoology, University College of Science, Mohanlal Sukhadia University, Udaipur, Rajasthan, India to observe the Role of egg, garlic and fenugreek during pregnancy and lactation in Swiss albino mice.

\section{Animals}

Healthy adult female Swiss mice 8-10 weeks old and $30 \mathrm{~g}$ average body weight were used for this study. Animals were obtained from the animal house of our department. Male and female mice in the ratio (1:4) were kept in the cages for mating. Female mice were examined every day in the morning and females showing vaginal plug were isolated and their gestation period were recorded. Presence of spermatozoa in the vagina on the following morning was considered day one of gestation. Confirmed pregnant females were housed in polyvinyl chloride cages $(270 \times 220 \times 140 \mathrm{~mm})$ wrapped with rice husk bedding, and maintained under standard laboratory conditions. The laboratory animals were kept in well ventilated animal room with relative humidity of 70$80 \%$. The room lighting consisted of alternate 12 hours light and dark periods. The animals had free access to food and water ad libitum. The maintenance and handling of the animals were done as per the guidelines of Purpose of Control and Supervision of Experimental Animals, Ministry of Environment and Forests, Government of India. The experimental protocols were approved by the Institutional Animal Ethical Committee of the University (No. CS/Res/07/759).

\section{Experimental design}

The selected pregnant females were separated in the following groups (six animals in each group), to study the variation in BW, CRL, BMI on PND 1, PND 7, PND 14, PND 21, PND 35 and PND 49 days.

Group I - Control diet $[(3.85 \mathrm{~g}$ Wheat $+3.85 \mathrm{~g}$ Maize $+1.55 \mathrm{~g}$ $\mathrm{Gram}+0.75 \mathrm{~g}$ Groundnut $=10 \mathrm{~g}$ ) for 1 mice $]$.

Group II - Control diet + High protein (Eggs) $[6 \mathrm{~g}+4 \mathrm{ml}]$ up to $21^{\text {st }}$ day of lactation

Group III - Control diet + Garlic (Bulb) $[9.5 \mathrm{~g}+0.5 \mathrm{~g}]$ up to $21^{\text {st }}$ day of lactation

Group IV - Control diet + Fenugreek (Seeds) $[9.5 \mathrm{~g}+0.5 \mathrm{~g}]$ up to $21^{\text {st }}$ day of lactation

Group V - Control diet + Egg + Garlic [5.5g+4 ml+0.5 g] up to $21^{\text {st }}$ day of lactation

Group VI - Control diet + Egg + Fenugreek [5.5 g + $4 \mathrm{ml}+0.5 \mathrm{~g}]$ up to $21^{\text {st }}$ day of lactation

Estimation of body weight (BW), crown to rump length (CRL) or body length (BL) and body mass index (BMI)

After fostered with different diets, mice were kept separately for 42 consecutive days ( 21 days of gestation and 21 days of lactation). BW and CRL of the control and experimental animals were taken on 1, 7, 14, 21, 35 
and 49 PND days after parturition. BW was estimated by WJ series electronic balance model No.WJ302A. CRL was estimated by measuring scale. From the data of BW and CRL body mass index (BMI) was calculated. The BMI was calculated for control and experimental mice at post natal days (PND) 1, 7, 14, 21, 35, 49 by using body weight and crown to rump body length. The body mass index (BMI) was calculated by the formula as described by Novelli et al. (2007).

\section{Body Mass Index $(\mathrm{BMI})=$ Body Weight $(\mathrm{g}) /$ Length $^{2}\left(\mathrm{~cm}^{2}\right)$}

The data was analyzed statistically using SPSS v. 17 (SPSS, Chicago, USA). The significance differences among means were carried out using Duncan's multiple range tests at $p<0.05$. The results were expressed as mean $\pm \mathrm{SD}$ of experiments.

\section{Results}

\section{Effect of different diets on body weight of neonates} on various postnatal days 1, 7, 14, 21, 35 and 49: Details of Body Weight (BW) in various experimental groups in comparison to control are shown in Table 1 and Fig. 1. Statistically highly significant $(p<0.01)$ changes were observed at PND 1 at the time of birth, PND 21 at the end of lactation, PND 35 at the time of puberty, PND 49 after puberty. At PND 1 H.P.D. treated group showed highest B.W. gain in comparison to all other experimental groups while all other groups showed similar results to one another. At PND 21 H.P.D. treated group showed highest B.W. gain in comparison to all other experimental groups while other experimental groups showed similar results. At PND 35 and 49 B.W. gain was highest in H.P.D. treated group in comparison to all other experimental groups, Garlic + H.P.D. and Fenugreek + H.P.D. treated groups showed similar results, garlic and fenugreek treated groups also showed similarity in changes.

The High protein Diet (H.P.D.) treated group showed much increased in body weight in comparison to Garlic, Fenugreek, Garlic + H.P.D and Fenugreek + H.P.D. treated groups. This shows that increased in body weight which occurs in H.P.D. treated group was balanced by garlic and fenugreek when given in combination with H.P.D. diet. This shows that garlic and fenugreek are weight controlling agent.

Table 1. Variations in Body Weight (BW) of neonates in different experimental groups on PND 1, PND 7, PND 14, PND 21, PND 35 and PND 49 days. Values are expressed as mean \pm S.D. for six females per group.

\begin{tabular}{lllllll}
\hline \multirow{2}{*}{ Groups } & \multicolumn{5}{l}{ Body Weight (BW) of neonates on following Postnatal days (PND) } \\
\cline { 2 - 7 } & PND 1 & PND 7 & PND 14 & PND 21 & PND 35 & PND 49 \\
\hline Control & $1.25 \pm 0.18^{\mathrm{b}, \mathrm{c}}$ & $2.74 \pm 0.31^{\mathrm{a}}$ & $4.37 \pm 0.35^{\mathrm{b}}$ & $6.11 \pm 0.19^{\mathrm{b}}$ & $12.90 \pm 0.23^{\mathrm{c}}$ & $23.17 \pm 0.83^{\mathrm{c}}$ \\
H.P.D. & $1.64 \pm 0.22^{\mathrm{a}}$ & $2.91 \pm 0.22^{\mathrm{a}}$ & $4.71 \pm 0.26^{\mathrm{a}}$ & $6.87 \pm 0.25^{\mathrm{a}}$ & $14.50 \pm 0.58^{\mathrm{a}}$ & $26.90 \pm 0.62^{\mathrm{a}}$ \\
Garlic & $1.25 \pm 0.10^{\mathrm{c}}$ & $2.73 \pm 0.31^{\mathrm{a}}$ & $4.35 \pm 0.32^{\mathrm{b}}$ & $6.10 \pm 0.29^{\mathrm{b}}$ & $12.80 \pm 0.36^{\mathrm{c}}$ & $22.52 \pm 0.92^{\mathrm{c}}$ \\
Fenugreek & $1.23 \pm 0.17^{\mathrm{c}}$ & $2.70 \pm 0.24^{\mathrm{a}}$ & $4.31 \pm 0.22^{\mathrm{b}}$ & $6.08 \pm 0.19^{\mathrm{b}}$ & $12.80 \pm 0.35^{\mathrm{c}}$ & $22.34 \pm 0.93^{\mathrm{c}}$ \\
Garlic + H.P.D & $1.35 \pm 0.07^{\mathrm{b}}$ & $2.82 \pm 0.26^{\mathrm{a}}$ & $4.46 \pm 0.43^{\mathrm{a}, \mathrm{b}}$ & $6.20 \pm 0.28^{\mathrm{b}}$ & $13.93 \pm 0.29^{\mathrm{b}}$ & $25.93 \pm 1.04^{\mathrm{b}}$ \\
Fenugreek + H.P.D. & $1.3 \pm 0.10^{\mathrm{b}, \mathrm{c}}$ & $2.78 \pm 0.23^{\mathrm{a}}$ & $4.40 \pm 0.34^{\mathrm{b}}$ & $6.18 \pm 0.30^{\mathrm{b}}$ & $13.78 \pm 0.48^{\mathrm{b}}$ & $25.46 \pm 1.08^{\mathrm{b}}$ \\
F-value & $19.662^{* *}$ & $1.198^{\mathrm{n}}$ & $2.268^{*}$ & $15.597^{* *}$ & $32.63^{* *}$ & $36.23^{* *}$ \\
\hline
\end{tabular}

$p$-value $>0.05=$ non-significant $(\mathrm{ns}),<0.05=$ significant $(*)$ and $<0.01=$ highly significant $(* *)$. Mean followed by the same alphabet within columns are not significantly different $(p<0.05)$ using Duncan's multiple rang test.

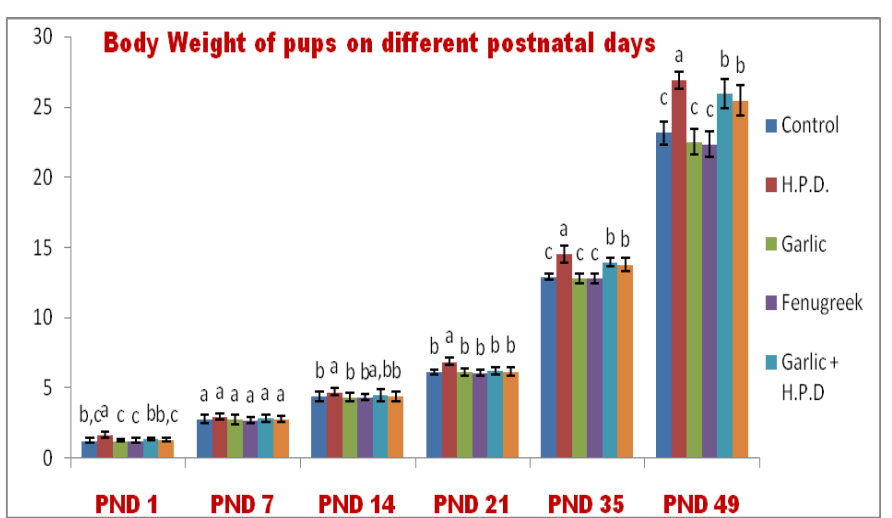

Fig. 1: Variations in Body Weight (BW) of neonates in different experimental groups on PND 1, PND 7, PND 14, PND 21, PND 35 and PND 49 days.
Statistically significant $(p<0.05)$ changes occurred at PND 14 at the end of second week. The B.W. increased was highest in H.P.D. treated group in comparison to other groups when compared to control group while statistically non significant $(p>0.05)$ changes occurred at PND 7 at the end of first week in all experimental groups in comparison to control group. At PND 7 no observable changes occurred in all experimental groups in comparison to control.

\section{Effect of different diets on body length of neonates} on various postnatal days 1, 7, 14, 21, 35 and 49: Details of Body Length (BL) in various experimental groups in comparison to control are shown in Table 2 
and Fig. 2. Statistically highly significant $(p<0.01)$ changes were observed at PND 1 at the time of birth, PND7 at the end of first week, PND 14 at the end of second week, PND 21 at the end of lactation. At all these PND's CRL reduction occurred highest in H.P.D. treated group while all other experimental groups showed similarity in their results.

The High Protein Diet (H.P.D.) treated group showed much decrease in body length in comparison to Garlic,
Fenugreek, Garlic + H.P.D and Fenugreek + H.P.D. treated group. This shows that decrease in body length which occurred in H.P.D. treated group was balanced by garlic and fenugreek when given in combination with H.P.D. diet. Statistically non significant $(p>0.05)$ changes occur at PND 35 at the time of puberty, PND 49 after puberty. The decrease in body length which occurred in H.P.D. treated group in comparison to other groups was balanced by garlic and fenugreek when given in combination with H.P.D.

Table 2. Variations in Body Length (BL) of neonates in different experimental groups on PND 1, PND 7, PND 14, PND 21, PND 35 and PND 49 days. Values are expressed as mean \pm S.D. for six females per group.

\begin{tabular}{lllllll}
\hline \multirow{2}{*}{ Groups } & \multicolumn{5}{l}{ Body Weight $($ BW) of neonates on following Postnatal days (PND) } \\
& PND 1 & PND 7 & PND 14 & PND 21 & PND 35 & PND 49 \\
\hline Control & $2.35 \pm 0.20^{\mathrm{a}}$ & $3.13 \pm 0.19^{\mathrm{a}}$ & $3.94 \pm 0.46^{\mathrm{a}}$ & $4.89 \pm 0.43^{\mathrm{a}}$ & $6.3 \pm 0.26^{\mathrm{a}}$ & $6.5 \pm 0.36^{\mathrm{a}}$ \\
H.P.D. & $2.03 \pm 0.18^{\mathrm{b}}$ & $2.63 \pm 0.24^{\mathrm{c}}$ & $3.07 \pm 0.46^{\mathrm{b}}$ & $4.13 \pm 0.46^{\mathrm{b}}$ & $6.01 \pm 0.33^{\mathrm{a}}$ & $6.27 \pm 0.18^{\mathrm{a}}$ \\
Garlic & $2.33 \pm 0.16^{\mathrm{a}}$ & $3.1 \pm 0.18^{\mathrm{a}}$ & $3.92 \pm 0.43^{\mathrm{a}}$ & $4.87 \pm 0.38^{\mathrm{a}}$ & $6.22 \pm 0.25^{\mathrm{a}}$ & $6.43 \pm 0.19^{\mathrm{a}}$ \\
Fenugreek & $2.3 \pm 0.21^{\mathrm{a}}$ & $3.05 \pm 0.22^{\mathrm{a}}$ & $3.88 \pm 0.40^{\mathrm{a}}$ & $4.85 \pm 0.38^{\mathrm{a}}$ & $6.20 \pm 0.26^{\mathrm{a}}$ & $6.4 \pm 0.13^{\mathrm{a}}$ \\
Garlic + H.P.D & $2.28 \pm 0.19^{\mathrm{a}}$ & $2.82 \pm 0.23^{\mathrm{b}}$ & $3.65 \pm 0.35^{\mathrm{a}}$ & $4.65 \pm 0.26^{\mathrm{a}}$ & $6.15 \pm 0.28^{\mathrm{a}}$ & $6.35 \pm 0.16^{\mathrm{a}}$ \\
Fenugreek + H.P.D. & $2.25 \pm 0.25^{\mathrm{a}}$ & $2.72 \pm 0.23^{\mathrm{b}, \mathrm{c}}$ & $3.72 \pm 0.44^{\mathrm{a}}$ & $4.7 \pm 0.25^{\mathrm{a}}$ & $6.19 \pm 0.22^{\mathrm{a}}$ & $6.39 \pm 0.17^{\mathrm{a}}$ \\
F-value & $4.94^{* *}$ & $13.39^{* *}$ & $7.276^{* *}$ & $5.791^{* *}$ & $1.23^{\mathrm{ns}}$ & $1.02^{\mathrm{ns}}$ \\
\hline p-value $>0.05$ = non-significant $(\mathrm{ns}),<0.05=$ significant $(*)$ and $<0.01=$ highly significant $(* *)$. Mean followed by the same \\
alphabet within columns are not significantly different $(p<0.05)$ using Duncan's multiple rang test.
\end{tabular}

Table 3. Variations in Body Mass Index (BMI) of neonates in different experimental groups on PND 1, PND 7, PND 14, PND 21, PND 35 and PND 49 days. Values are expressed as mean \pm S.D. for six females per group.

\begin{tabular}{lllllll}
\hline \multirow{2}{*}{ Groups } & \multicolumn{6}{l}{ Body Weight $($ BW) of neonates on following Postnatal days (PND) } \\
& PND 1 & PND 7 & PND 14 & PND 21 & PND 35 & PND 49 \\
\hline Control & $0.23 \pm 0.04^{\mathrm{b}}$ & $0.28 \pm 0.05^{\mathrm{c}}$ & $0.29 \pm 0.04^{\mathrm{b}}$ & $0.26 \pm 0.03^{\mathrm{b}}$ & $0.33 \pm 0.03^{\mathrm{d}}$ & $0.55 \pm 0.03^{\mathrm{c}}$ \\
H.P.D. & $0.41 \pm 0.03^{\mathrm{a}}$ & $0.43 \pm 0.04^{\mathrm{a}}$ & $0.53 \pm 0.03^{\mathrm{a}}$ & $0.42 \pm 0.03^{\mathrm{a}}$ & $0.40 \pm 0.04^{\mathrm{a}}$ & $0.68 \pm 0.04^{\mathrm{a}}$ \\
Garlic & $0.23 \pm 0.03^{\mathrm{b}}$ & $0.28 \pm 0.05^{\mathrm{c}}$ & $0.29 \pm 0.03^{\mathrm{b}}$ & $0.26 \pm 0.03^{\mathrm{b}}$ & $0.33 \pm 0.02^{\mathrm{b}, \mathrm{c}}$ & $0.54 \pm 0.03^{\mathrm{c}}$ \\
Fenugreek & $0.24 \pm 0.04^{\mathrm{b}}$ & $0.30 \pm 0.05^{\mathrm{c}}$ & $0.29 \pm 0.04^{\mathrm{b}}$ & $0.26 \pm 0.04^{\mathrm{b}}$ & $0.37 \pm 0.03^{\mathrm{b}, \mathrm{c}}$ & $0.54 \pm 0.03^{\mathrm{c}}$ \\
Garlic + H.P.D & $0.27 \pm 0.05^{\mathrm{b}}$ & $0.36 \pm 0.04^{\mathrm{b}}$ & $0.34 \pm 0.03^{\mathrm{b}}$ & $0.29 \pm 0.04^{\mathrm{b}}$ & $0.37 \pm 0.03^{\mathrm{b}}$ & $0.64 \pm 0.04^{\mathrm{a}, \mathrm{b}}$ \\
Fenugreek + H.P.D. & $0.27 \pm 0.04^{\mathrm{b}}$ & $0.38 \pm 0.08^{\mathrm{b}}$ & $0.33 \pm 0.04^{\mathrm{b}}$ & $0.28 \pm 0.03^{\mathrm{b}}$ & $0.36 \pm 0.03^{\mathrm{b}, \mathrm{c}}$ & $0.63 \pm 0.04^{\mathrm{b}}$ \\
F-value & $19.23^{* *}$ & $11.337^{* *}$ & $11.91^{* *}$ & $12.82^{* *}$ & $7.75^{* *}$ & $15.01^{* *}$ \\
\hline
\end{tabular}

$p$-value $>0.05=$ non-significant $(\mathrm{ns}),<0.05=$ significant $(*)$ and $<0.01=$ highly significant $(* *)$. Mean followed by the same alphabet within columns are not significantly different $(p<0.05)$ using Duncan's multiple rang test.

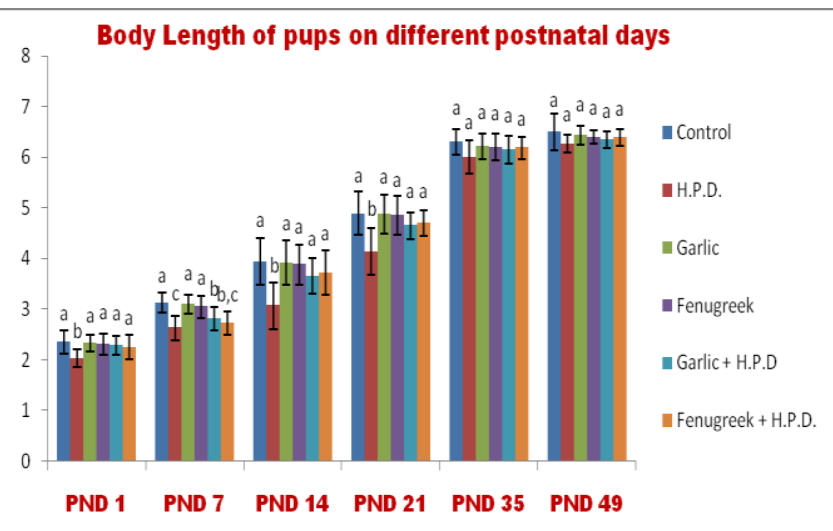

Fig. 2: Variations in Body Length (BL) of neonates in different experimental groups on PND 1, PND 7, PND 14, PND 21, PND 35 and PND 49 days.

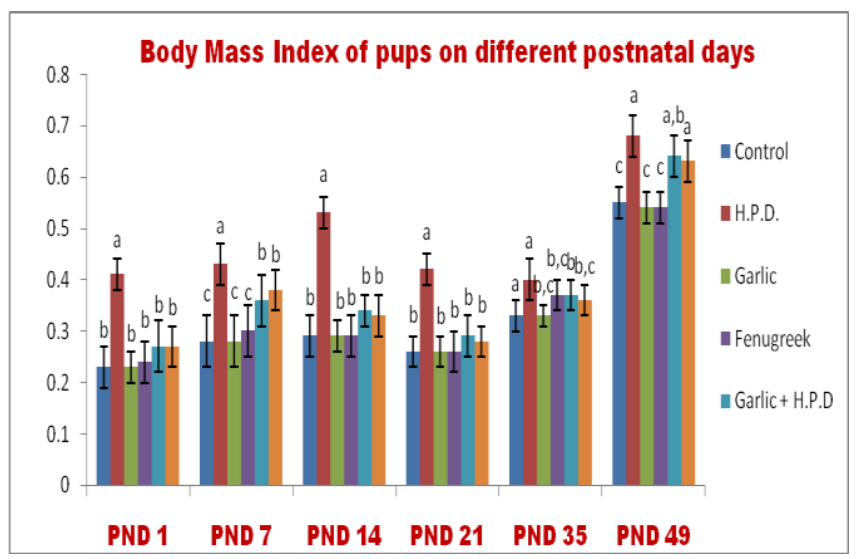

Fig. 3: Variations in Body Mass Index (BMI) of neonates in different experimental groups on PND 1, PND 7, PND 14, PND 21, PND 35 and PND 49 days. 
3. Effect of different diets on body mass index of neonates on various postnatal days 1, 7, 14, 21, 35 and

49: Details of Body Mass Index (BMI) in various experimental groups in comparison to control are shown in Table 3 and Fig. 3. Statistically highly significant $(p<0.01)$ changes were observed at all days PND 1, at the time of birth, PND7 at the end of first week, PND 14 at the end of second week, PND 21 at the end of lactation, PND 35 at the time of puberty and at PND 49 after puberty. The BMI was highest in H.P.D. treated group at all PND days in comparison to all other experimental groups.

\section{Discussion}

Malnutrition in uterus is viewed as causing the fetus to undergo structural and functional changes that result in an increased risk for diseases and physiological impairment in adulthood (Sayer et al., 2001). It was demonstrated that protein rich diet increases nitrogen in the body tissues, followed by urea production in liver (Morens et al., 2000) and also decreases urine $\mathrm{pH}$ (Fellstrom et al., 1983). It was also demonstrated that low protein diet leads to higher level of reactive oxygen species in the body. It was also found by experiments in rats that protein malnutrition in mother results in decreased postnatal lactase and alkaline phosphatase activities in small intestine which reduce gastrointestinal function in neonates (Zeman et al., 1973). Muramatsu and Ashida (1961) conducted an experiment on male weanling rats of the Wistar strain. The rats were fed with basal diet containing $25 \%$ of casein (high protein diet) after that rats weighing 55 to 60 grams were separated into groups and they were fed on 0 to $60 \%$ casein, 85 to $25 \%$ of alpha potato starch and so on. They observed that growth rate increased as level of casein increased from 0 to $25 \%$ in the diet and $60 \%$ of casein diet however produces lower weight gain.

The total body weight and body length is an important parameter which could indicate the animal's physiological health status. Such parameter can be influenced by the quantity and the quality of the consumed diet. The animals in our study when given H.P.D., we found that H.P.D. enhanced B.W. gain and CRL reduction. In consequences the gain in the $\mathrm{B} . \mathrm{W}$. and reduction in CRL could be as a result nutritional composition of egg which leads to B.W. gain and CRL reduction because as demonstrated above that protein rich diet increases nitrogen in our body tissue. Our result are similar to Ulusoy and Bren (2008) who also observed in high protein fed diet group loss of weight in first weeks $(8.2 \%)$ and the later weight gain exceeding the initial body weight $(4.7 \%)$ was observed. In our study also highly significant increase occur at PND 14, PND 21, PND 35 and PND 49 days.

In the present investigation B.W. gain and CRL reduction was found highest in H.P.D. treated group in comparison to all other experimental groups at all PND days. When H.P.D is given in combination with Garlic and Fenugreek the gain in B.W. and CRL was reduced. This occurred because garlic has been reported to be effective in reducing body weight in rats. Ademiluyi et al. (2013) conducted a research to investigate the ameliorating effect of dietary inclusion of $2 \%$ or $4 \%$ Allium sativum on gentamycin induced hepatotoxicity in rats. They observed a significant weight loss. Kim et al. (2011) done research on beneficial effect of black garlic extract on obesity and hyperlipidemia in rats. They firstly fed rats with the high fat diet; than these rats were fed with garlic extract $(100,250$ and $500 \mathrm{mg} / \mathrm{kg}$ body weight). They observed that body weight of rats fed with high fat diet was increased in these rats in comparison to normal diet. After administrating these rats with garlic extract the body weight was significantly decreased. Allicin is considered as the major scavenging and antioxidant compound (Chung, 1999; Sharma et al., 2010) due to which garlic shows all its important properties.

Rahman et al. (2012) worked on antioxidant properties of raw garlic (Allium sativum) extract, he observed that allicin in garlic shows antioxidant property based on the results of the DPPH scavenging. According to Lee et al. (2011) the reduced body weight could be due to a decreased in the mass of the fat in the garlicsupplemented groups, reflected a marked antiobesity effect of garlic. Antiobesity action of garlic could be as a result of the fact that it enhances fecal mass and frequency of fecal excretion, probably due to its fiber composition, and hence would increase fecal loss of energy. Similarly, some researchers indicated that fenugreek seed extract supplementation help in reducing the body and adipose tissue weight (Handa et al., 2005). According to Geetha et al. (2011) fenugreek seed extract supplementation reduces the body and adipose tissue weight. The probable mechanism of fenugreek decreasing the total body and adipose tissue weight may be that (a) fenugreek flushes out the carbohydrates from the body before they enter the blood stream resulting in weight loss (b) Fenugreek seeds contain a high proportion (40\%) of soluble fiber. This fiber forms a gelatinous structure which may have effects on slowing 
the digestion and absorption of food from the intestine and creates a sense of fullness in the abdomen, thus suppresses appetite and promotes weight loss.

Our results are also in agreement with above researchers we have also observed weight loss when garlic and fenugreek are given in combination with H.P.D. but when given alone with control diet no major changes occurred in BW and CRL.

\section{Conclusion}

On the basis of above findings we can conclude that diet especially high protein diet influences the body weight and body length of neonates it increases the body weight of the neonates while decreases the body length of the neonates because high protein food especially egg is a source of nitrogen and single source of cholesterol among the foods commonly eaten which affects the body weight and body length of organism. Garlic and fenugreek is the weight controlling agent so when given in combination with high protein diet balances the weight of the neonates because as we have discussed above that both garlic and fenugreek shows antioxidant property due to this property they maintain the body's physiology.

\section{Conflict of interest statement}

Authors declare that they have no conflict of interest.

\section{Acknowledgement}

Authors are thankful to the Department of Zoology, College of Science, M. L. S. University for providing necessary facilities for the present piece of research work.

\section{References}

Ademiluyi, A.O., Oboh, G., Owoloye, T.R., Agbebi, O.J., 2013. Modulatory effects of dietary inclusion of garlic (Allium sativum) on gentamycin-induced hepatotoxicity and oxidative stress in rats. Asian Pac. J. Trop. Biomed. 3(6), 470-475.

Agarwal, S., Sohal, RS., 1994. Aging and protein oxidation damage, Mech. Aging Dev. 75(1), 11-19.

Astley, S.B., Elliott, R.M., Archer, D.B., Southon, S., 2004. Evidence that dietary supplementation with carotenoids and carotenoid-rich foods modulates the DNA damage: repair balance in human lymphocytes. Br. J. Nutr. 91(1), 63-72.

Beckman, K.B., Ames, B.N., 1998. The free radical theory of aging matures. Physiol. Rev. 78(2), 547-81.
Butte, N.F., King, J.C., 2005 Energy requirements during pregnancy and lactation. Public Health Nutr. 8(7A), 101027.

Chu, S.Y., Callaghan, W.M., Kim, S.Y., Schmid, C.H., Lau, J., England, L.J., Dietz, P.M., 2007. Maternal obesity and risk of gestational diabetes mellitus. Diabetes Care 30(8), 2070-2076.

Chung, J.G., 1999. Effects of butylated hydroxyanisole (BHA) and butylated hydroxytoluene (BHT) on the acetylation of 2-aminofluorene and DNA-2-aminofluorene adducts in the rat. Toxicol. Sci. 51(2): 202-21.

Cui, K., Luo, X., Xu, K., Ven Murthy, M.R., 2004. Role of oxidative stress in neurodegeneration: recent developments in assay methods for oxidative stress and nutraceutical antioxidants. Prog. Neuropsychopharmacol. Biol. Psych. 28(5), 771-799.

Fellstrom, B., Danielson, B.G., Karlstrom, B., Lithell, H., Ljunghall, S., Vessby, B., 1983. The influence of a high dietary intake of purine rich animal protein on urinary urate excretion and super saturation in renal stone disease. Clin. Sci. 64(4), 399-405.

Geetha, M., Suneel, K.R., Krupanidhi, A.M., Muralikrishna, K.S., Avin, A.P., Prashanth, P., 2011. Effect of Fenugreek on Total Body and Organ Weights: A Study on Mice. Pharmacologyonline 3, 747-752.

Halliwell, B., Aeschbach, R., Loliger, J., Aruoma, O.I., 1995. The characterization of antioxidants. Food Chem .Toxicol. 33(7), 601-617.

Halliwell, B., Gutteridge, J.M.C., 1999. Free Radicals in Biology and Medicine, $2^{\text {nd }}$ Edn. Clarendon Press, Oxford University Press.

Handa, T., Yamaguchi, K., Sono, Y., Yazawa, K., 2005. Effects of fenugreek seed extract in obese mice fed a highfat diet. Biosci. Biotechbol. Biochem. 69(6), 1186-8.

Johnson, I.T., 2004. New approaches to the role of diet in the prevention of cancers of the alimentary tract. Mutat. Res. 551 (1-2), 9-28.

Jones, M.L., Mark, P.J. Waddell, B.J. 2014. Maternal dietary omega-3 fatty acids and placental function. Reprod. 147(5), 143-152.

Joshipura, K.J., Ascherio, A., Manson, J.E., Stampfer, M.J., Rimm, E.B., Speizer, F.E., Hennekens, C.H., Spiegelman, D., Willett, W.C., 1999. Fruit and vegetable intake in relation to risk of ischemic stroke. J. Med. Assoc. 28(13), 1233-1239.

Joshipura, K.J., Hu, F.B., Manson, J.E., Stampfer, M.J., Rimm, E.B., Speizer, F.E., Colditz, G., Ascherio, A., Rosner, B., Spiegelman, D., Willett, W.C., 2001. The effect of fruit and vegetable intake on risk for coronary heart disease. Ann. Intern. Med. 134(12), 1106-1114.

Kerver, J.M., Park, Y., Song, W.O., 2002. The role of eggs in American diets: health implications and benefits. In: Eggs and Health Promotion (Ed.: Watson R.). Blackwell Publishing Co., Iowa. pp.9-18.

Kim, I., Kim, J.Y., Hwang Y.J., Hwang K. A., Om, A.S., Kim J.H., Cho, K.J., 2011. The beneficial effects of aged black garlic extract on obesity and hyperlipidemia in rats fed a 
high-fat diet. J. Med. Plants Res. Vol. 5(14), pp. 31593168.

Lee, M.S., Kim, I.H., Kim, C.T., Kim, Y., 2011. Reduction of body weight by dietary garlic is associated with an increase of uncoupling protein mRNA expression and activation of AMP-activated protein kinase in diet-induced obese mice. J. Nutr. 141(11), 1947-1953.

Levine, R.L., 2002. Carbonyl modified proteins in cellular regulation, aging and disease. Free Radic. Biol. Med. 32(9), 790-796.

Morens, C., Gaudichoni, C., Metges, C.C., Fromentin, G., Baglieri, A., Even, P.C., Huneau, J.F., Tome, D., 2000. A high-protein meal exceeds anabolic and catabolic capacities in rats adapted to a normal protein diet. J. Nutr. 130(9), 2312-2321.

Muramatsu, K., Ashida, K., 1961. Effect of dietary protein level on growth and liver enzyme activities of rats. J. Nutr. 76(2), 143-150

NIH (US National Institutes of Health), 2009. Dietary supplement fact sheet: Vitamin D.

Novelli, E.L.B., Diniz, Y.S., Galhardi, C.M., Ebaid, G.M., Rodrigues, H.G., Mani, F., Fernandes, A.A., Cicogna, A.C., Novelli Filho, J.L., 2007. Anthropometrical parameters and markers of obesity in rats. Lab. Anim. 41(1), 111-119.

Pipkin, F.B., 2007. Maternal Physiology. In: Dewhurst's Textbook of Obstetrics and Gynaecology (Ed.: Edmonds, D. K.). Blackwell Publishing, Oxford, UK.

Prentice, A.M., Goldberg, G.R., 2000. Energy adaptations in human pregnancy: limits and long-term consequences. Am. J. Clin. Nutr. 71(5S), 1226-32.

Rahman, M. M., Fazlic, V., Saad, N. W., 2012. Antioxidant properties of raw garlic (Allium sativum) extract. Int. Food Res. J. 19(2), 589-591.
Riboli, E., Norat, T., 2003. Epidemiologic evidence of the protective effect of fruit and vegetables on cancer risk. Am. J. Clin. Nutr. 78(3S), 559-569.

Ron, J., Levitz, M., Chuba, J., Dancis, J., 1984. Transfer of 25 hydroxyvitamin D3 and 1,25-dihydroxyvitamin D3 across the perfused human placenta. Am. J. Obstet. Gynecol. 148(4), 370-374.

Sayer, A.A., Dunn, R., Langley-Evans, S., Cooper, C., 2001. Prenatal exposure to a maternal low protein diet shortens life span in rats. Gerontol. 47(1), 9-14.

Schneider, H., Möhlen, K.H., Dancis, J., 1979. Transfer of amino acids across the in vitro perfused human placenta. Pediatr. Res. 13, 236-240.

Sharma, V., Sharma, A., Kansal, L., 2010. The effect of oral administration of Allium sativum extracts on lead nitrate induced toxicity in male mice. Food Chem. Toxicol. 48(3), 928-936.

Ulusoy, E., Eren, B., 2008. Histological Changes on Liver Glycogen Storage in Mice (Mus musculus) Caused by Unbalanced Diets. Clin. Med. Pathol. 2008(1), 69-75.

World Cancer Research Fund/American Institute for Cancer Research, 2007. Food, Nutrition, Physical Activity, and the Prevention of Cancer: a Global Perspective. AICR, Washington DC.

Young, I.S., Woodside, J.V., 2001. Antioxidants in health and disease. J. Clin. Pathol. 54(3), 176-186.

Zeman, F.J., Shrader, R.E., Allen, L.H., 1973. Persistent effects of maternal fetal deficiency in postnatal rats. Nutr. Rep. Int. 7, 421-436.

\section{How to cite this article:}

Sharma, R., Jaitawat, A., Jain, N., Rani, D., Suthar, M., 2016. Role of egg, garlic and fenugreek during pregnancy and lactation in Swiss albino mice. Int. J. Curr. Res. Biosci. Plant Biol. 3(4), 32-38. doi: http://dx.doi.org/10.20546/ijcrbp.2016.304.006 